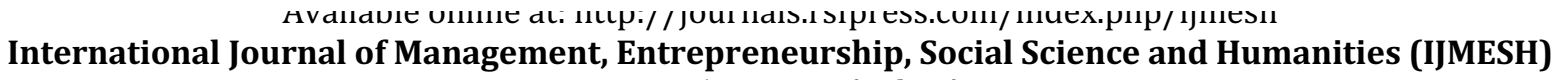
ISSN 2580-0981 (online)

Volume 4 Number 2 (2021): 1-10

\title{
The Work Performance of Married Female Employees during Covid-19 Pandemic
}

\author{
Yohana F. Cahya Palupi Meilani' ${ }^{1}$ Ian Nurpatria Suryawan'2, Fetty Asmaniati ${ }^{3}$ \\ Nurbaeti4, Myrza Rahmanita5 \\ ${ }^{1}$ Faculty of Economics and Business, Pelita Harapan University, Tangerang, Indonesia \\ ${ }^{2}$ Management Department, Trisakti School of Management, Jakarta, Indonesia \\ ${ }^{3}$ Trisakti School of Tourism, Jakarta, Indonesia \\ ${ }^{4}$ Trisakti School of Tourism, Jakarta, Indonesia \\ ${ }^{5}$ Trisakti School of Tourism, Jakarta, Indonesia
}

\begin{abstract}
The research aims to determine the effect of learning organizations on married female permanent employees' performance at restaurants in Jakarta and Bali by mediating job satisfaction and organizational commitment. The phenomenon that occurs is that married female employees at restaurants tend to work less optimally and are reluctant to participate in development training programs since the Covid-19 pandemic in early 2020. This quantitative research was conducted with purposive random sampling on 73 married female employee respondents. The measuring instrument is a questionnaire with five-Likert scales-data processing using CB-SEM with Smart PLS program. The results showed a significant influence of learning organizations on female staff performance through the mediation of job satisfaction and organizational commitment. The research contribution is expected to provide input to the management at restaurants in managing the performance of married female employees.
\end{abstract}

Keywords: Female Employee; Learning Organization; Performance; Satisfaction; Restaurant

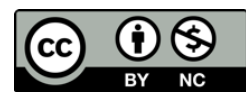

This is an open access article under the CC-BY-NC license.

\section{INTRODUCTION}

The better and the development of each employee's behavior, attitudes, and performance will result in the strength of human resources (HR) or a company and vice versa. Companies need to manage each member of the company's behavior to have human resources whose capabilities and behavior align with the company strategy and goals. Likewise, restaurants engaged in Jakarta and Bali and has 826-line employees and administrative staff for supporting employees. The administrative staff is at the forefront of making business processes run smoothly. The majority of the administrative employees are 143 people. There are 73 married female employees at restaurants. An interview with the HRD Manager on 18 June 2020 showed some problems the married female employees faced. The problems ranged from standard work performance, were reluctant to work overtime, and less interested in attending training outside working hours. Also, only a few staff were willing to participate in career development or further education since the beginning of the Covid 19 pandemic in 2020. Those conditions might lead to some work mistakes. During the Covid-19 pandemic, as a restaurants company, it maintains its production by applying standard health protocols. Employees are required to wear masks, wash their hands, and keep their distance.

Besides, the layout of the office staff is made with a distancing condition of approximately two meters. Each incoming staff has been regularly checked using a serology test by HRD every two weeks for free. 
International Journal of Management, Entrepreneurship, Social Science and Humanities (IJMESH), Vol. 4 (2), 1-10

The Work Performance of Married Female Employees during Covid-19 Pandemic

Yohana F. Cahya Palupi Meilani; Ian Nurpatria Suryawan; Fetty Asmaniati; Nurbaeti; Myrza Rahmanita

The female employees were selected as the research object for their dual roles, both as the company employees and homemakers. During the pandemic, the employees still have to work, except for Large-Scale Social Restrictions (PSBB). At this time, female staff still needs to fulfill domestic duties

and job roles. In this case, an exploratory study was carried out on 30 married female employees to determine the factors affecting their work achievement. Job satisfaction, the highest value factor that could affect performance, was chosen by 29 out of 30 respondents, with the percentage of $96.67 \%$, organizational learning $90 \%$, organizational commitment $86.67 \%$, work relationship $83.33 \%$, motivation $80 \%$, job description $70 \%$, incentive bonus $66.67 \%$, salary $16.4 \%$.

Organizational learning is defined as something that can make a difference to an organization compared to its competitors (Kanten et al., 2014). So, the Learning Organization refers to a culture of introducing learning covering individual and group learning (Kanten et al., 2014). The relationship between employees and the company is crucial, and the reciprocity will increase employee productivity, which can keep employees loyal to the company. Organizational commitment and job satisfaction are related to attitudes and get several researchers' attention (Azeem, 2010). It is because committed and satisfied employees will have high performance and contribute to productivity (Azeem, 2010).

Organizational commitment is an essential component in organizational behavior and human resources (Dhar, 2014). Organizational commitment is vital because it is a good predictor of organizational goals, attendance, turnover, and worker productivity (Almutairi, 2016). Based on the above background, it is essential to discuss organizational learning's effect on performance through job satisfaction and organizational commitment as mediating variables for married female employees.

The research questions are formulated as the following:

1. Does the Learning Organization positively affect the Job Satisfaction of married female employees?

2. Does the Learning Organization positively affect the Organizational Commitment of married female employees?

3. Does the Learning Organization positively affect the Employee Performance of married female employees?

4. Does Job Satisfaction positively affect the Employee Performance of married female employees?

5. Does Organizational Commitment positively affect the Employee Performance of married female employees?

Then the research aims to determine the effect of learning organizations on married female permanent employees' performance at restaurants in Jakarta and Bali by mediating job satisfaction and organizational commitment. While the research contribution is expected to provide input to the management at restaurants in managing the performance of married female employees during pandemic covid-19.

\section{LITERATURE REVIEW}

\section{Organizational Learning and Job Satisfaction.}

Organizational learning refers to the development and acquisition of organizational knowledge, understanding, techniques, and practices to increase organizational effectiveness (Armstrong, 2014, 299) and again emphasized by Ehrenberg et al. (1994: 279-80) as cited in Armstrong, $(2014,287)$ on understanding and individual skills that come from education and training, as well as training gained from experience, generate productive capital. Hendri (2019) conducted a study entitled "The Mediation Effect of Job Satisfaction and Organizational Commitment on Employee Performance's Organizational Learning Effect." The results show that organizational learning is considered an essential factor preceding employee job satisfaction and organizational commitment. Job satisfaction results from employees thinking about how good their work is to make everything look important through their work, Luthans (2002) cited in Hendri (2019). 
Job satisfaction leads to the attitude (emotional reaction) of an individual to his job. After employee job satisfaction is achieved, then the employee's organizational commitment will be accomplished as well. This study supports the general hypothesis that organizational learning has a significant and positive effect on job satisfaction. Thus, the learning organization has a strong and positive influence on employee attitudes, namely job satisfaction and organizational commitment. Allouzi et al. (2018) also reported that Learning Organization positively impacts Job Satisfaction. Watkins et al. (2003), as cited in Hendri (2019), explain that organizations conducted with positive learning and training can increase employee satisfaction. For that in the first hypothesis:

$H_{1}$ : Learning Organization positively affects the job satisfaction of married female employees

\section{Organizational Learning and Organizational Commitment.}

Commitment is related to how individuals feel about their organization. Three characteristics of commitment identified by Mowday et al. (1982), as cited in Broweys (2015), are to have a strong willingness to remain a member of an organization; have high trust and can accept values in the organization; be ready to put forth considerable effort on behalf of the organization. Purcell et al. (2003) in Armstrong (2014) identified the key to commitment. It covers participation in the previous year's training, satisfaction with the career path, satisfaction with the performance appraisal system, perceived good leadership, perceived the job as challenging, perceive the company helps them achieve a work-life balance, and satisfaction with communication or corporate performance. Hendri (2019) reported that employee organizational commitment means identifying a strong person's involvement in the organization. Organizational commitment reflects a loyalty to the organization. It is a process by which employees express their concern for the organization's achievement of organizational goals. Learning Organization has a significant and positive relationship to Organizational Commitment. Research conducted by (Ryu et al., 2019) showed that learning affected organizational commitment positively. Hendri (2019) contended that knowledge and understanding of organizational commitment makes a positive contribution to management in managing employees. It can be concluded that Learning Organization has a positive effect on Organizational Commitment. It leads to the second hypothesis:

$\mathrm{H}_{2}$ : Learning Organization positively affects Organizational Commitment.

\section{Organizational Learning and Employee Performance.}

Organizational learning for individuals can be achieved if there is a social transfer of knowledge between individuals to various other individuals due to a shared interpretation. Baker et al. (1999) in Jiménez (2011) confirmed a positive relationship between organizational learning and performance that learning orientation directly affects organizational performance. Other studies have also found a positive relationship between organizational learning and performance (Keskin, 2006; Ussahawanitchakit, 2008 in Jiménez, 2011). Bontin et al. (2010) in Jiménez (2011) also provide evidence of a positive relationship between organizational learning and performance, discussing learning at three levels: individuals, groups, and organizations. Tippins et al. (2003) in Jiménez (2011) showed that the five distinct stages in the learning process (information acquisition, information dissemination, shared interpretation, declarative memory, and procedural memory) have a positive relationship to performance. The main objective in conducting organizational learning is always to improve the quality and quantity and quality of performance to help companies (Demarest (1997) in Ramírez (2011)). In short, organizational learning can improve performance. It leads to the third hypothesis:

$\mathrm{H}_{3}$ : Learning Organization positively affects employee performance.

\section{Job Satisfaction and Employee Performance}

Job satisfaction is a fundamental factor in human resource management since employee satisfaction strongly correlates with performance. Previous studies have reported the positive influence of job satisfaction on performance (Juniantara, 2015; Minkara, 2015). Job satisfaction is required for employees to improve their performance even though it varies relatively among individuals, as Sutrisno (2011) reported in Arda (2017). When employees are satisfied, they will have a feeling of happiness, and this feeling enables them to become more productive individuals. Employee job 
International Journal of Management, Entrepreneurship, Social Science and Humanities (IJMESH), Vol. 4 (2), 1-10

The Work Performance of Married Female Employees during Covid-19 Pandemic

Yohana F. Cahya Palupi Meilani; Ian Nurpatria Suryawan; Fetty Asmaniati; Nurbaeti; Myrza Rahmanita

satisfaction will result in better job outcomes (Hendri (2019; Minkara (2015). The higher the satisfaction, the better the employee performance will be. Thus, the fourth hypothesis is the following:

$H_{4}:$ Job Satisfaction positively affects Employee Performance.

\section{Organizational Commitment and Employee Performance.}

Organizational commitment has been widely investigated to see its relationship with performance. Hendri (2019) and Setyorini (2012) showed that individuals with good credibility tend to have an exemplary work commitment, and they are willing to do part of their contribution to the work organization. It means that they will put in a better effort and work hard to affect their productivity. Yamanie et al. (2016) also emphasize the importance of managing organizational commitment to achieve better individual performance. In line with Yamanie et al. (2016), Nurmaningsih (2017) also reported that better organizational commitment would impact better performance. For that in the fifth hypothesis, the following:

$H_{5}$ : Organizational Commitment positively affects Employee Performance.

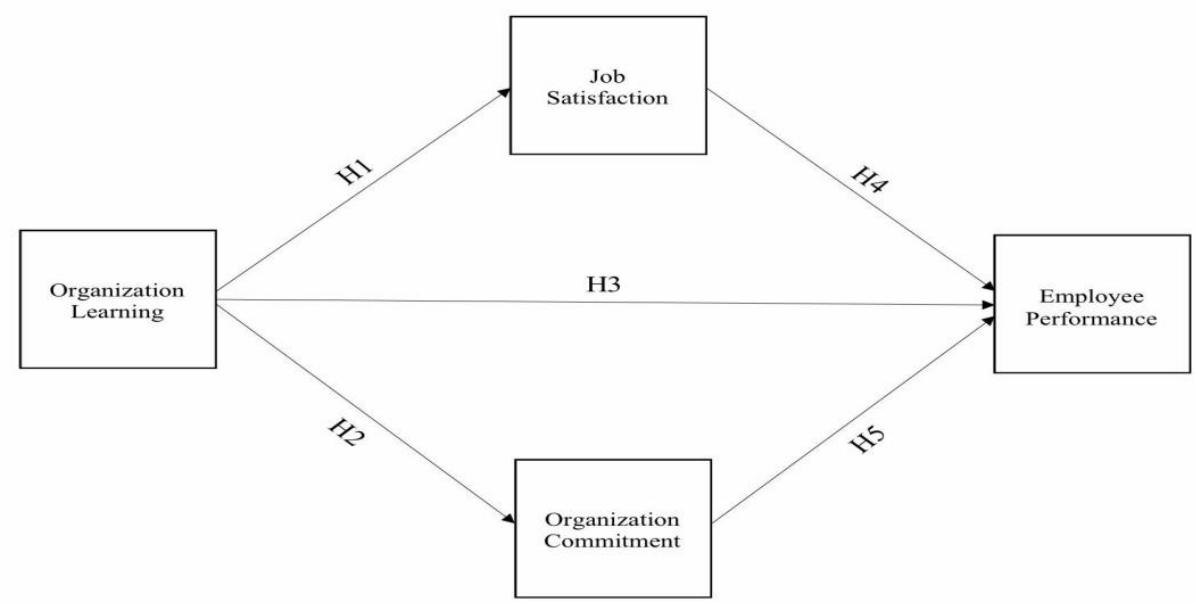

Figure 1. Research Model

Source : (Research Model, 2020)

\section{RESEARCH METHODOLOGY}

This study is quantitative descriptive in nature with data to describe each research variable. The research subjects are married female employees and have been permanent employees for more than one year. It was conducted with a non-random sampling approach. Purposive sampling is used to select as many as seventy-three (73) people who meet the requirements to become respondents. The unit of research analysis is individual. The data collection tool used a questionnaire with five (5) Likert scale from strongly disagree to strongly agree. A neutral scale is maintained to value the respondent's opinion. The research indicators were adapted from several previous studies. The organization learning variable was adapted from Hendri (2019) and Ryu et al. (2019) with the following statements (clear job information from superiors; increased knowledge in completing work; job challenges; gaining motivation, and a learning program provided by the company. Job Satisfaction Variable is adapted from Hendri (2019) with the following statement (responsibility is given according to ability; salary is based on what the employees do; promotions are by work results; good working relationships between employees; approval with superior leadership). Organizational Commitment variables are adapted from Hendri ( 2019) and Ryu et al. (2019), with this statement (confident that they can accept the company's goals; accept the company's values; willing to work hard in every job; want to keep working in this company; sharing company problems). Instruments for Employee Performance variable is adapted from Hendri (2019).

The statements comprise achieving the target profession; integrity in every job; honesty in every job; 
enthusiasm for achieving work goals; works well with colleagues, planning well; making decisions well; setting up a good working relationship). In testing the validity of the construct, convergent validity and discriminant validity are used. Convergent validity was measured with Average Variance Extracted (AVE) and loading factors. According to Ghozali et al. (2015), the AVE results must be more than 0.5; the loading factor must be more than 0.7. Discriminant validity is performed by looking at each variable's AVE's square root, which is greater than each variable's correlation in the model. The variable reliability uses composite reliability, which is reliable if Cronbach's Alpha and Composite Reliability value is more than 0.7. Data processing uses the Smart PLS program to test the outer model (measurement) and the inner model (structural).

\section{FINDING AND DISCUSSION}

The respondents' age range from 24 to 41 years old and the majority has undergraduate education (S1)

\section{MEASUREMENT MODEL (Outer Model)}

The outer model is used to determine the relationship among latent variables on the indicator, with the average variance extracted (AVE), convergent validity, and the latent constructs' discriminant validity. Then the reliability is measured by the composite reliability for the indicators of the variables.

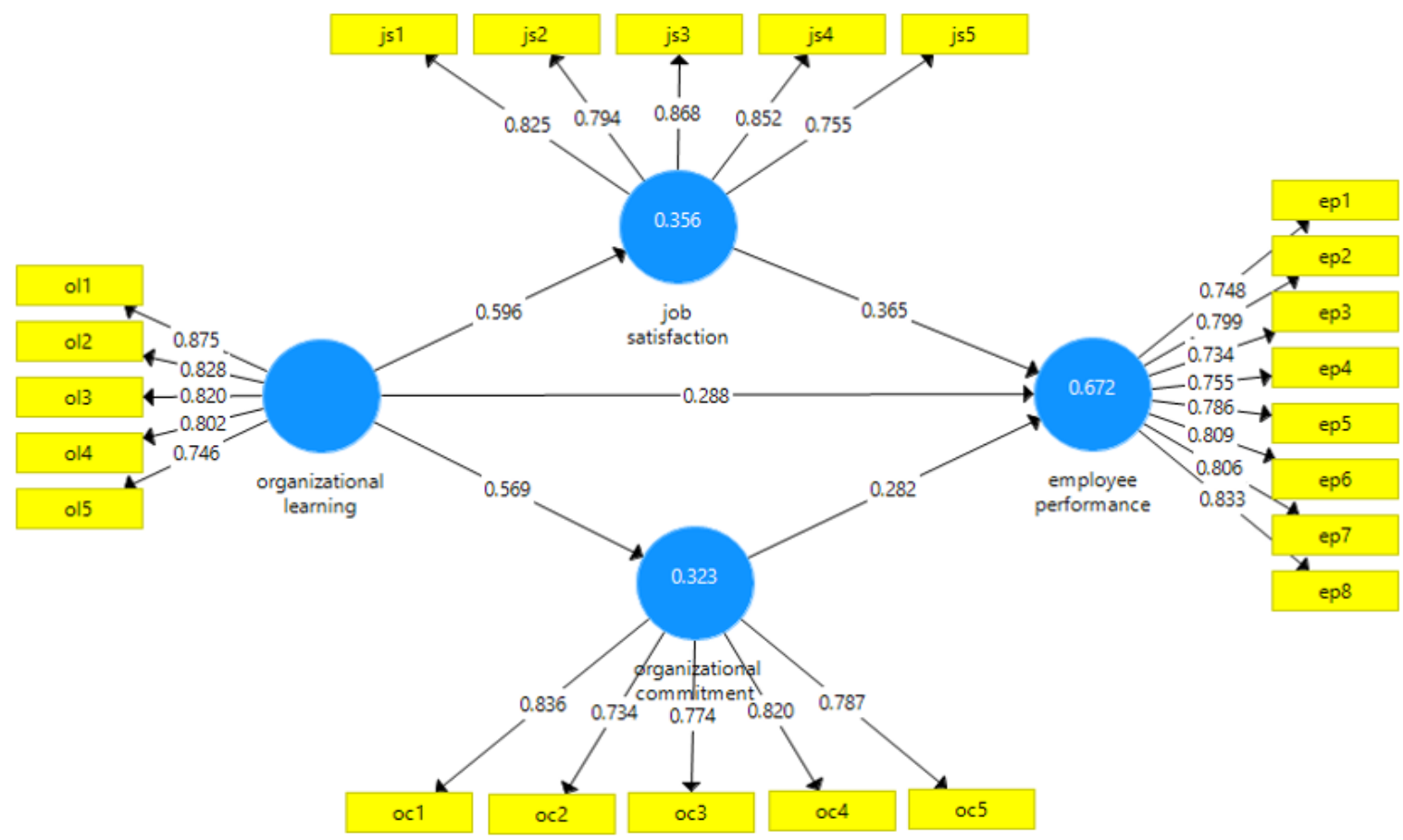

Figure 2. Model Structural Relationship

Source: (Processed data, 2020)

All indicators have a loading factor above 0.7 , so they are valid. AVE test results in Table 1 . also show all valid variables.

Table 1. AVE Test Results

\begin{tabular}{ccc}
\hline Variable & Average Variance Extracted (AVE) & Remark \\
\hline$O L$ & 0,665 & Valid \\
$J S$ & 0,672 & Valid
\end{tabular}


International Journal of Management, Entrepreneurship, Social Science and Humanities (IJMESH), Vol. 4 (2), 1-10

The Work Performance of Married Female Employees during Covid-19 Pandemic Yohana F. Cahya Palupi Meilani; Ian Nurpatria Suryawan; Fetty Asmaniati; Nurbaeti; Myrza Rahmanita

\begin{tabular}{ccc}
$O C$ & 0,626 & Valid \\
$E P$ & 0,616 & Valid \\
\hline
\end{tabular}

Table 2. Fornel Lacker Discriminant

\begin{tabular}{ccc}
\hline Variable & Composite Reliability & Remark \\
\hline$O L$ & 0,908 & Reliable \\
$J S$ & 0,911 & Reliable \\
$O C$ & 0,893 & Reliable \\
$E P$ & 0,927 & Reliable \\
\hline \multicolumn{3}{c}{ Source: (Processed data, 2020) }
\end{tabular}

Then, the Fornel Lacker test results for reliability calculations are displayed, showing that each variable has a square root value of AVE higher than the relationship's value. It means that the discriminant validity has been fulfilled.

Table 3. Composite Reliability Test

\begin{tabular}{ccccc}
\hline & OC & EP & JS & OL \\
\hline OC & 0,793 & & & \\
EP & 0,738 & 0,765 & & \\
JS & 0,784 & 0,755 & 0,82 & \\
OL & 0,569 & 0,676 & 0,596 & 0,814 \\
\hline \multicolumn{5}{c}{ Source: (Processed data, 2020) }
\end{tabular}

The reliability test is seen from the composite reliability value according to table 3 .

\section{STRUCTURAL MODEL (Inner Model)}

The structural model is tested by looking at the multicollinearity of the Variance Inflation Factor (VIF) value. The VIF calculation results of all indicators in this study have a VIF value below 5 , meaning they do not have high collinearity. Furthermore, the structural model can also be evaluated by looking at the R2 value. The results of R2 explain the influence of the independent variables on JS (job satisfaction), OC (organizational commitment), and EP (performance). R-Square on OL's effect on JS is 0.356 , meaning that OL can explain $35.6 \%$ of JS.

Table 4. Hypothesis Test Results

\begin{tabular}{ccccc}
\hline Hypothesis & $\begin{array}{c}\text { Original } \\
\text { Sample (0) }\end{array}$ & T Statistics (|0/ STDEV|) & $\begin{array}{c}\text { P } \\
\text { Values }\end{array}$ & Remark \\
\hline$O L-J S$ & 0,596 & 7,917 & 0 & H1 Accepted \\
$O L-O C$ & 0,569 & 6,59 & 0 & H2 Accepted \\
$O L-E P$ & 0,288 & 2,451 & 0,015 & H3 Accepted \\
$J S-E P$ & 0,365 & 2,105 & 0,036 & H4 Accepted \\
\hline
\end{tabular}




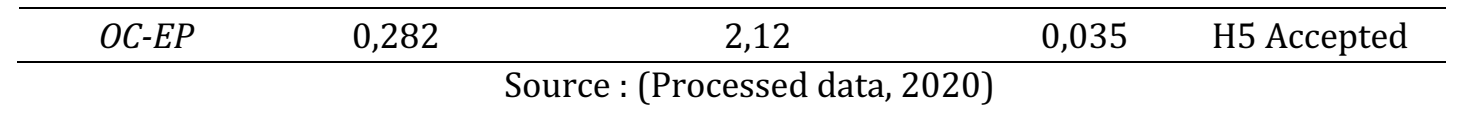

OL can be explained by OC $32.3 \%$. R-Square on the effect of OL, JS, and OC on EP is 0.672 . It means that $67.2 \%$ of the $\mathrm{OL}$, JS, and OC variables can explain EP, which is included in the strong category. Other factors explain the remaining $32.8 \%$ outside of research, such as employee involvement variables, organizational citizenship behavior (Sugianingrat et al., 2017). Likewise, with the variable role ambiguity, role conflict, excessive role, and self-esteem (Akgunduz, 2014)

\section{HYPHOTESIS TEST RESULTS}

The significance value determines the effect between the independent and dependent variables through the mediating variable. A bootstrapping procedure was carried out to correct the PLS estimate error standard, namely, as recommended by Ghozali and Latan (2015), as much as 1000.

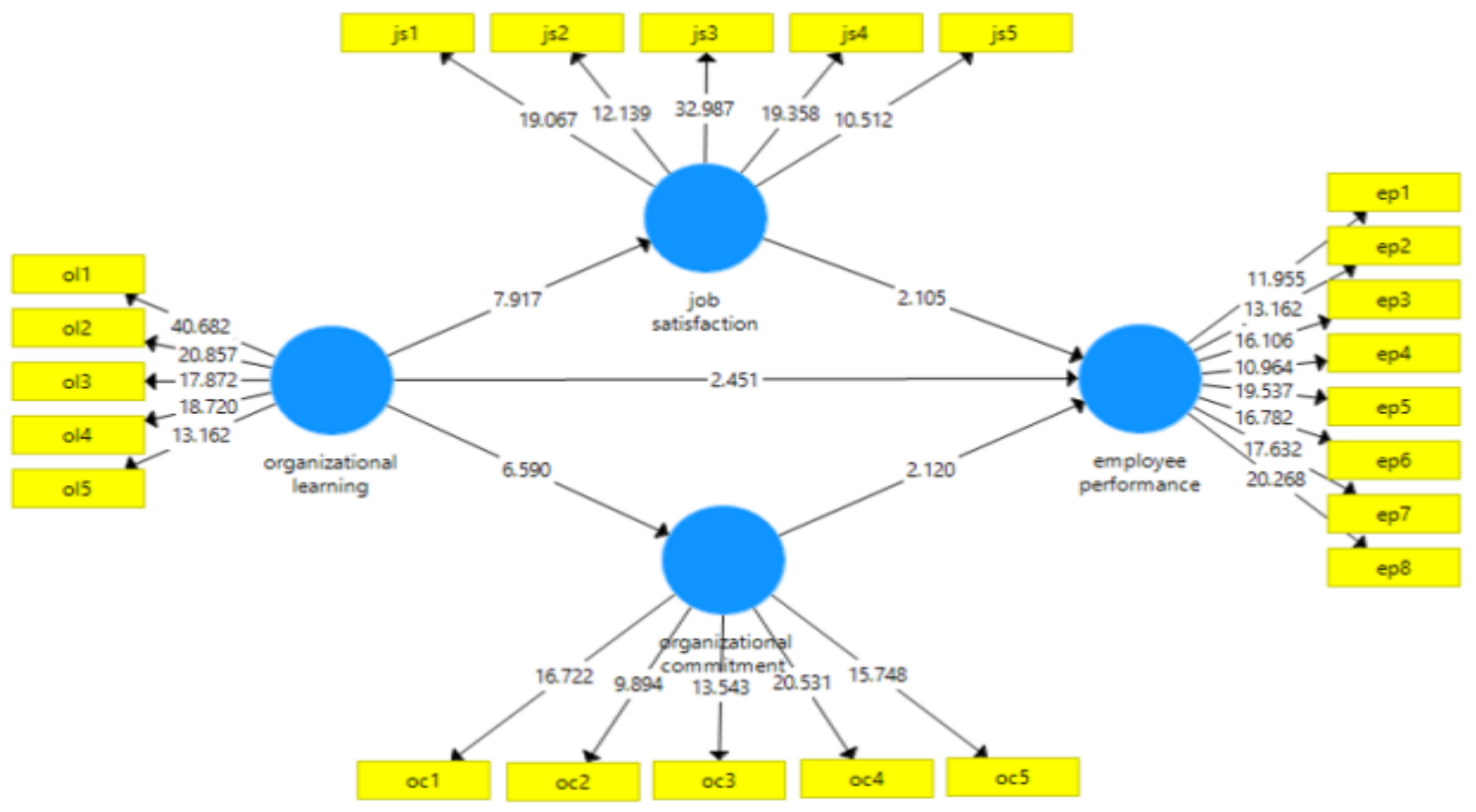

Figure 3. Estimation Results of the PLS (Bootstrapping) Model Source: (Processed data, 2020)

The results of the calculation of the hypothesis test can be seen in table 4 .

The first hypothesis, stating that OL positively affects JS, has a t-statistic of 7,917 from a predetermined benchmark; namely, the t-statistic has a minimum limit of 1.96 and a p-value of 0,000 . Thus, the first hypothesis is accepted. It confirmed that organizational learning has a significant effect on job satisfaction. This study supports the research of Allouzi et al. (2018) and Hendri (2019). Thus, the higher the organizational learning of married female employees, the higher their perceived job satisfaction. In this case, restaurants needs to improve OL by providing detailed and measurable work information on KPIs and to build an atmosphere of formal and non-formal knowledge sharing. The company needs to provide a series of training and shows the importance of training for married female employees. Therefore, they can understand and carry out their duties and responsibilities more optimally, not just feeling satisfied with the work results that are not optimal. The head of the work unit can be appointed to enhance married female employees' knowledge and abilities by providing challenges or motivation. Married female employees carry out dual roles both at work and at home, so 
International Journal of Management, Entrepreneurship, Social Science and Humanities (IJMESH), Vol. 4 (2), 1-10

The Work Performance of Married Female Employees during Covid-19 Pandemic

Yohana F. Cahya Palupi Meilani; Ian Nurpatria Suryawan; Fetty Asmaniati; Nurbaeti; Myrza Rahmanita

it is necessary to teach good time management to have a work-life balance, especially in the Covid-19 pandemic conditions. Besides maintaining health and safety at work, it also needs stress management programs for married female employees by providing online counseling services or online yoga.

The second hypothesis affirming OL affects OC. The results show that organizational learning positively affects organizational commitment with a t-statistic of 6,590, which means that it exceeds 1.96 and a p-value of 0,000 , so the hypothesis is accepted. This hypothesis supports Armstrong (2014), Broweys (2015), Ryu (2019), and Hendri (2019). In improving organizational learning on organizational commitment, management can perform various activities through appropriate learning programs to gain essential job knowledge and capacity building. Rotation in related jobs can be conducted to avoid boredom and provide work experiences for learning enhancement.

The third hypothesis stating that OL significantly affects EP has a t-statistic of 2.451; it can be concluded that the hypothesis is accepted. Higher organizational empowerment will improve employee performance. The results of this study support Ramirez (2011) and Jimenez (2011). Apart from the formal face-to-face training provided through internal or external of restaurants, it is necessary to consider conducting online training; thus, married female employees can still carry out online-based learning to improve their performance. To improve Organizational learning towards Employee performance of restaurants, married female employees can be requested to attend nonformal training, coaching mentoring, or employee gatherings. Those activities aim to establish good relationships and teamwork cohesiveness, initiated from conducting activities outside of their routine work. Those activities contribute to the success of performance: the spirit of cooperation and initiative leadership, which can impact morale. However, these findings do not support Hendri's (2019) research stating that organization learning has no effect on employee performance at PTPN XIII (Limited Liability Company) in West Kalimantan.

The fourth hypothesis states that the JS statement has a significant effect on EP, the t-statistic value is 2.105, so this hypothesis is accepted. The results of this study support the research of Juniantara (2015), Minkara (2015), Arda (2017), and Hendri (2019). It can be concluded that the higher the job satisfaction of married female employees, the better the resulting performance. The company can manage it by providing a proper reward system based on salary surveys in similar labor markets and offering skill-based pay or performance-based pay. This research confirmed that job satisfaction is essential for married female employees to improve individual performance even though, according to its nature, job satisfaction itself is very relative, or it varies from one person to another.

The fifth hypothesis, with the statement that OC has a significant effect on EP by referring to the tstatistic result of 2,120, then the hypothesis is accepted. These results support the research of Setyanngsih (2012), Yamanie (2016), Nurmaningsih (2017), Hendri (2019). During the Covid 19 pandemic, management can do several ways to maintain a good work environment by providing adequate facilities according to health protocol, such as providing disinfectant booths, masks, and vitamins for employees. The company can then provide suitable motivating strategies according to their work's needs to make married female employees accept and carry out values in line with company goals. Eventually, married female employees at restaurants will strive to achieve its job targets and have integrity in every job to enhance employee performance.

\section{CONCLUSION}

All hypotheses were accepted with a statistical t-value above 1.96 and a p-value above 0.00 . Then the coefficient of determination is classified as strong since they exceed $60 \%$. It means that the variables used in research, organizational learning (OL), job satisfaction (JS), and organizational commitment (OC), can explain performance (EP). Restaurant management needs to manage organizational learning with the online platform and pay attention to health protocols' requirements to reduce female staff's anxiety with families who want to participate. Employees who are satisfied with their job can manage flexible working time and maintain better internal communication relationships. Organizational commitment can also be increased by cultivating the importance of female family female staff's work to build a sustainable commitment in the long term. If those aspects are appropriately managed, 
married female employees will feel appreciated and become more enthusiastic about supporting work targets' achievement to become more high-performing.

\section{RESEARCH LIMITATIONS}

This study has several limitations based on variables, sampling technique, characteristics, number of samples, and time. The variables used in this study are limited to those included in the research model. Meanwhile, other variables can affect employee performance. The related variables can be the work environment, organizational culture, communication, and others. Besides, the sampling technique used in this study was purposive sampling. With the sample characteristics, the sample is only married, female staff. Apart from that, this study has a limited number of respondents, with only seventy-three (73). Therefore, this research cannot necessarily be generalized to a cross-sectional study.

\section{RECOMMENDATIONS FOR FURTHER RESEARCH}

Various suggestions are proposed for further research. First of all, it is crucial to research with a broader demographic area or not only from one sphere of society. Therefore, it can be used as a comparison to find out the characteristics of employees. Apart from that, it is hoped that future studies can add related variables, which is not explained in this study. Thus, factors that can affect employee performance, such as the work environment, organizational culture, communication, and other related topics, can be identified. This research uses the PLS method to test the predictive relationship between variables by seeing whether there is a relationship or one variable's influence on another. Future researchers are expected to use the SEM method to estimate the structural model based on strong theoretical studies to test the causality relationship between variables and measure the model's feasibility and confirm it according to empirical data.

\section{REFERENCES}

Abdillah, W., \& Hartono, J. (2015). Partial Least Square (PLS): alternatif structural equation modeling (SEM) dalam penelitian bisnis. Yogyakarta: Penerbit Andi, 22. pp.103-150

Armstrong, Michael; Taylor, Stephen. (2014). Armstrong's handbook of Human Resources Management Practice. Thirteenth Edition. pp. 5, 16, 23, 189-190, 287, 299

Azeem, S. M. (2010). Job satisfaction and organizational commitment among employees in the Sultanate of Oman. Psychology, 1(4)

Almutairi, D. 0. (2016). The mediating effects of organizational commitment on the relationship between transformational leadership style and job performance. International Journal of Business and Management, 11(1)

Argote, L. (2011). Organizational learning research: Past, present, and future. Management Learning, $42(4)$

Aziri, B. (2011). Job Satisfaction: A Literature Review. Management Research \& Practice, 3(4)

Allouzi, R. A. R., Suifan, T. S., \& Alnuaimi, M. (2018). Learning organizations and innovation mediated by job satisfaction. International Journal of Business and Economics Research, 7(1)

Arda, M. (2017). Pengaruh Kepuasan Kerja dan Disiplin Kerja Terhadap Kinerja Karyawan Pada Bank Rakyat Indonesia Cabang Putri HIjau Medan. Jurnal Imiah Manajemen dan $\quad$ Bisnis, 18(1)

Browaeys, M. J., \& Price, R. (2015). Understanding Cross-Cultural Management. Pearson 3rd Edition. pp. 32

Dhar, R. L. (2014). Service quality and the training of employees: The mediating role of organizational commitment. Tourism Management, 46

Ghozali, Imam. \& Latan, Hengky. Partial Least Square, Smart PLS 3.0. second edition. UNDIP.Semarang.Indonesia. pp. 3, 5, 7, 37, 73-75, 78, 80-81 
International Journal of Management, Entrepreneurship, Social Science and Humanities (IJMESH), Vol. 4 (2), 1-10

The Work Performance of Married Female Employees during Covid-19 Pandemic Yohana F. Cahya Palupi Meilani; Ian Nurpatria Suryawan; Fetty Asmaniati; Nurbaeti; Myrza Rahmanita

Hendri, M. I. (2019). The mediation effect of job satisfaction and organizational commitment on the organizational learning effect of the employee performance. International Journal of Productivity and Performance Management

Hair Jr, J. F., Sarstedt, M., Hopkins, L., \& Kuppelwieser, V. G. (2014). Partial least squares structural equation modeling (PLS-SEM). European business review

Juniantara, I. W., \& Riana, I. G. (2015). Pengaruh motivasi dan kepuasan kerja terhadap kinerja

karyawan koperasi di Denpasar. E-Jurnal Ekonomi dan Bisnis Universitas Udayana

Jiménez-Jiménez, D., \& Sanz-Valle, R. (2011). Innovation, organizational learning, and performance. Journal of business research, 64(4)

Kanten, P., Kanten, S., \& Gurlek, M. (2014). The effects of organizational structures and learning organization on job embeddedness and individual adaptive performance. Procedia Economics and Finance, (23)

Taurisa, M.C., \& Intan, R. (2012). Analisis pengaruh budaya organisasi dan kepuasan kerja terhadap komitmen organisasional dalam meningkatkan kinerja karyawan (Studi pada PT. Sido Muncul Kaligawe Semarang). Jurnal Bisnis dan ekonomi, 19(2)

Noe; Hollenbeck; Gerhart; Wright (2014). Fundamentals of Human Resources Management. Mcgraw Hill Education. Sixth Edition. pp. 3(350)

Nurnaningsih, S., \& Wahyono, W. (2017). Pengaruh Kepuasan Kerja, Motivasi Kerja dan Komitmen Organisasi terhadap Kinerja Melalui Organizational Citizenship Behaviour (OCB) sebagai Variabel Intervining. Economic Education Analysis Journal, 6(2)

Ramírez, A. M., Morales, V. J. G., \& Rojas, R. M. (2011). Knowledge creation, organizational learning, and their effects on organizational performance. Engineering Economics, 22(3)

Ryu, G., \& Moon, S. G. (2019). The effect of actual workplace learning on job satisfaction and organizational commitment. Journal of Workplace Learning

Sekaran, U. and Bougie, R. (2013). Research Methods for Business: A Skill-Building Approach., Wiley, New York. 6th Edition. pp. 303

Sekaran, U. and Bougie, R. (2016). Research Methods for Business: A Skill- Building Approach. Wiley, New York. 7th Edition. pp. 37, 43-44, 72-73, 79, 95-105, 159-160, 220, 222-223, 279, 282-284

Sugianingrat, I.A.P.W., Kerti Yasa, N.N., Sintaasih, D.K., dan Subudi, M. (2017): The influence of ethical leadership on employee performance through employee engagement. IOSR Journal of Humanities And Social Science

Setyorini, C. T., Maghfiroh, S., \& Farida, Y. N. (2012). Pengaruh Komitmen Organisasi, Budaya Organisasi, dan Keterlibatan Kerja Terhadap Kinerja Karyawan Baitul Maal Wat Tamwil (BMT). Media Riset Akuntansi, 2(1)

Susmiati, S., \& Sudarma, K. (2015). Pengaruh Budaya Organisasi dan Dukungan Organisasi Persepsian terhadap Kinerja Karyawan dengan Komitmen Organisasi sebagai Variabel Intervening. Management Analysis Journal, 4(1)

Yamanie, I. Y., \& Syaharuddin, Y. (2017). Pengaruh penilaian prestasi kerja, komitmen organisasi dan disiplin kerja terhadap kinerja karyawan pada PT. Pelabuhan Indonesia IV cabang Samarinda. Jurnal Manajemen, 8(1) 